\title{
Some Aspects of Reproduction in Long Whiskered Catfish, Sperata aor (Hamilton 1822), from North-East Bangladesh
}

\author{
Md. Naimuddin Jabed ${ }^{1}$, Mohammad Amzad Hossain ${ }^{1,4, *}$ (D), Sohel Mian ${ }^{1}$, \\ Muhammad Anamul Kabir ${ }^{2}$, Sabuj Kanti Mazumder ${ }^{3}$, Mohammed Mahbub Iqbal ${ }^{1}$
}

\author{
${ }^{1}$ Sylhet Agricultural University, Faculty of Fisheries, Department of Fish Biology and Genetics, Sylhet-3100, Bangladesh. \\ ${ }^{2}$ Sylhet Agricultural University, Faculty of Fisheries, Department of Aquaculture, Sylhet-3100, Bangladesh. \\ ${ }^{3}$ Bangabandhu Sheikh Mujibur Rahman Agricultural University, Faculty of Fisheries, Department of Genetics and Fish Breeding, \\ Gazipur-1706, Bangladesh. \\ ${ }^{4}$ Central Queensland University, Costal Marine Ecosystem Research Centre, QLD 4680, Australia.
}

\section{How to cite}

Jabed, N., Hossain, M.A., Mian, S., Kabir, M.A., Mazumder, S.K., Iqbal, M.M. (2021). Some Aspects of Reproduction in Long Whiskered Catfish, Sperata aor (Hamilton 1822), from North-East Bangladesh. Aquaculture Studies, 21 , $47-54$. http://doi.org/10.4194/2618-6381-v21_2_01

\section{Article History \\ Received 16 September 2020 \\ Accepted 24 December 2020 \\ First Online 08 February 2020 \\ Corresponding Author \\ Tel.: +8801724882492 \\ E-mail: mamzad.fbg@sau.ac.bd}

\author{
Keywords \\ Sperata aor \\ GSI \\ Fecundity \\ Reproduction \\ Nesting
}

\begin{abstract}
Different reproductive aspects such as sexual maturity, spawning, gonadosomatic index, fecundity, and histological changes in gonads of captive reared Sperata aor were investigated for a period of one year. Male and female fish were identified by based on morphological characteristics. The spawning season was found to be extended from May-August. Gonadosomatic index reaches maximum in August and lowest in September. Absolute fecundity varied from 59255 to 70586 with an average value of 64920. Absolute fecundity had been reported to be increased with total length, body weight. Histological study of ovary of $S$. aor indicated the presence of four developmental stages viz, early perinucleolar s oocytes, late perinucleolar oocytes, yolk vesicle stage and yolk granular stage. Findings reveal that, $S$. aor has group asynchronous manner of ovarian growth and used to spawn numerous times in a year under favorable environmental conditions. The testes histology represents the presence of spermatocyte, spermatid, and spermatozoa. This species builds nests during breeding season and fries are found within the nests.
\end{abstract}

\section{Introduction}

Giant Catfishes belonging to Bagride family and Sperata genus, are very popular and common freshwater habitant of South Asia with a promising nutritive and commercial value (Iqbal et al., 2018). To the date four species i.e., S. acicularis, S.aor, S. aorella and $S$. seenghala belonged to this genus has been identified in Bangladesh. The long whiskered catfish, Sperrata aor is one of the critically endangered fish species in Bangladesh (IUCN Bangladesh, 2015). Once it was a common dweller of rivers and canals in Afghanistan, Pakistan, India, Nepal, Bangladesh and Myanmar, but now its abundance has been declined due to over harvesting and countless ecological deviations in natural aquatic environment (Khan \& Nazir, 2019). Therefore, the Sperata $s p$. is now being considered as a one of diminishing indigenous fish fauna of India subcontinent (Khan et al., 2016; Nazir \& Khan, 2017).

Fishes are diversified vertebrates group and shows very distinctive reproductive strategies based on species, ecology and environment (Bolis et al., 2001). This diversity is tending to be high largely due to enormous numbers of fish species (Volff, 2005). A detailed information of reproduction is key to proper management of aquaculture and natural fisheries (Hossain et al., 2017; Jannatul et al., 2015; Mian et al., 2020)). Different allometric such as length-weight relationship, gonadosomatic index (GSI), fecundity and breeding peaks of fish are vital information regarding conservation and sustainable harvesting of any fishery stock (Mian et al., 2020; Uddin et al., 2017). The values of gonado-somatic index govern the maturation phase and spawning onset in several fish species. Histological 
observation of gonad provides onset of maturation phases and spawning term of a species. Reproductive biology is especially concern to hatchery managers who depend on size at first sexual maturity and on the ontogeny spawning development (Neto, 2005). To begin the induced breeding system and culture in indoor controlled environments, it is indispensable to have data on breeding biology, season, and reproductive potentiality of a species. Therefore, current research has been undertaken to find out the key information of reproduction in $S$. aor at captivity.

\section{Materials and Methods}

\section{Experimental Design and Nesting Observation}

Fishes were stocked in total 6 ponds (each pond is of $40.5 \mathrm{~m}^{2}$ ) at 20 stocking density. Animals were feed efficiently twice daily around 10:00 am at morning and $4.30 \mathrm{pm}$ at afternoon hours with artificial pelleted feed composed of dietary $38-40 \%$ crude protein, $13 \%$ moisture, $6 \%$ fiber and $3 \%$ crude fat. The feeding rate was maintained around $2.5-3 \%$ body weight of fish. Live small shrimp were also given weekly as live feed. Three experimental ponds covering each of $80.92 \mathrm{~m}^{2}$ area were selected for observation of nesting behavior and morphology of nest formation. The ponds were nearly dry up to observe the nests.

\section{Fish Sampling}

Series of monthly field sampling and pond treatment was done for a period of twelve months started from July 2018 to June 2019. Laboratory assays were conducted in the laboratory of Fish Biology and Genetics, Sylhet Agricultural University, Sylhet. Field collected samples were bring back to laboratory to collect morphometrics data, and to identify their sex and maturation stages. Following the dissection, a piece of gonad had been preserved in neutral buffered formalin for histology.

\section{Gonadosomatic Index (GSI) and Fecundity Estimation}

Following the dissection of mature male and female fish, the weight of the gonad has been taken carefully to calculate GSI using formula from Brooks et al., (1997).

$$
\mathrm{GSI}=\frac{\text { weight of gonad }}{\text { weight of body }} \times 100
$$

Only matured ovary ready to spawn was selected for determination of fecundity. Total numbers of oocytes in whole ovary were accounted by following the equation from Rahman \& Samat, (2020).

$$
N=\left(W_{t} / W_{s}\right) \times N s
$$

Where: $\mathrm{Wt}=$ total weight of the gonad, $\mathrm{Ws}=$ weight of each subsample, and Ns=numbers of individual oocytes in each subsample.

\section{Histological and Microscopic Observation of Gonads}

Standard histological procedure described by VanDyk \& Pieterse, (2008) has been followed to perform the histological study of gonad samples. Histological slides were examined under compound light microscope and images were taken with the attached digital camera (Olympus Xcam-Alpha, Germany) and maturation stages were identified according to the features described by Feist, (2009).

\section{Data Analysis}

All statistical data was treated by inputting in using Microsoft Excel sheet and analyzed in IBM SPSS 26. Variance between group means were justified by oneway analysis of variance (ANOVA) and Duncan's multiple range test and all the significance was established at $\mathrm{P}<0.05$.

\section{Results}

\section{Sex Determination}

Entire body surface of all the male brood fishes was inflamed and bright reddish in color during July-August. A thick milky white fluid secretion or scum formed on their body surface (Figure 1.A-B). Further, dissection and histological investigation also confirmed them as male. All mature male parade a pointed genital papilla which is typical to most of teleost. The abdomen of the female brood fishes was softening, swollen, and rounded, the genital opening tends to be ovate, protruded, and reddish in all mature fish (Figure 1.C-D).

\section{GSI and Fecundity of S. aor}

The gonado-somatic index showed a well gradual rising from September to August. The GSI values were fluctuated between $0.47 \pm 0.04$ to $3.00 \pm 0.02$ and $1.08 \pm 0.01$ to $0.12 \pm 0.01$ for female and male $S$. aor respectively during the period of August to July (Figure 2). Higher peaks for GSI were detected during June to August from $2.60 \pm 0.03$ to $3.00 \pm 0.02$ and $0.86 \pm 0.01$ to $1.08 \pm 0.01$ for female and male respectively (Figure 2 ).

The fecundity had been accounted by sacrificing 24 randomly allocated mature female brood encompassing total length ranged between $46.83 \pm 0.15 \mathrm{~cm}$ to $51.33 \pm 0.19 \mathrm{~cm}$, weight from $901.41 \pm 20.81 \mathrm{gm}$ to $1084.56 \pm 12.07 \mathrm{gm}$ and ovary weight from $20.96 \pm 0.12$ $\mathrm{gm}$ to $32.56 \pm 048 \mathrm{gm}$. The fecundity was found to be fluctuated from $59255.17 \pm 184.03$ to $70048.86 \pm 131.99$ (Table 1). There was no significant difference between the fecundity from May and June as well from between and July August (Table 1). 


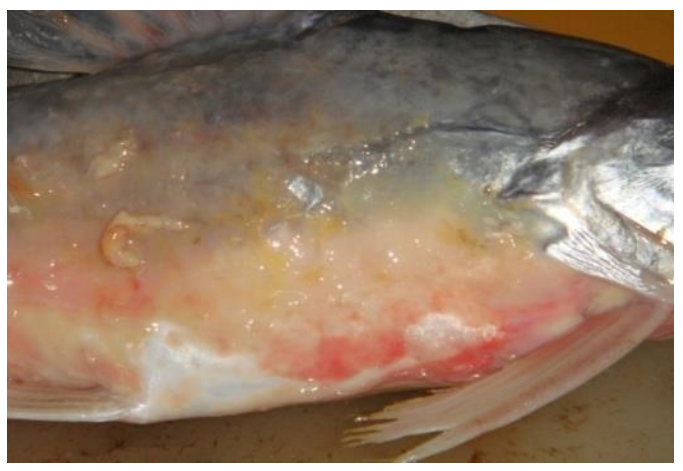

A

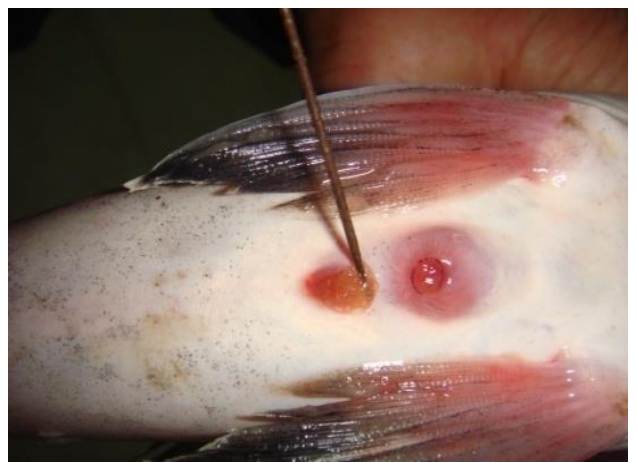

C

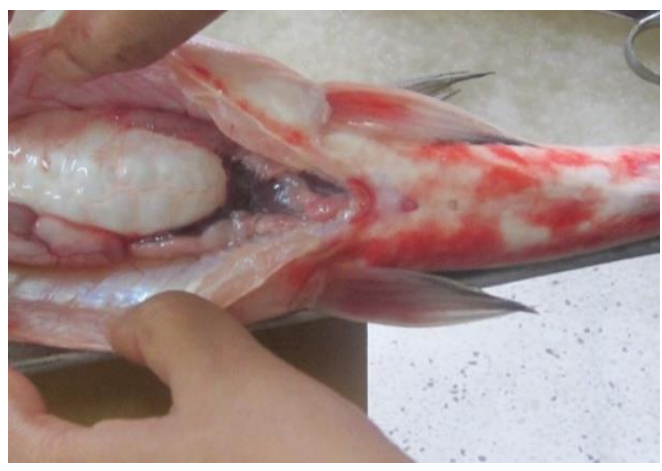

B

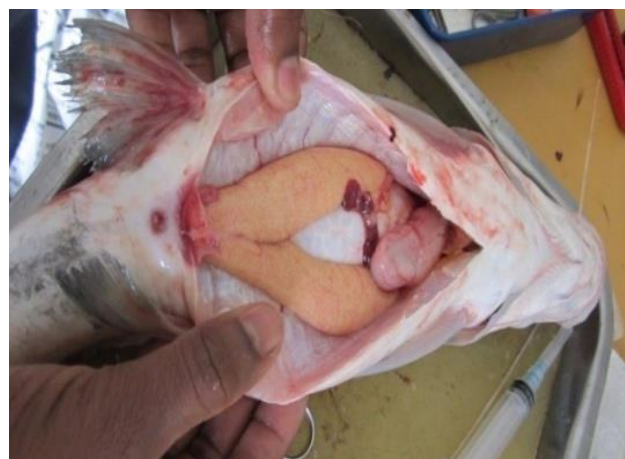

D

Figure 1. A-B. Thick milk like scum on the mature male S. aor; C-D. Female genital opening.

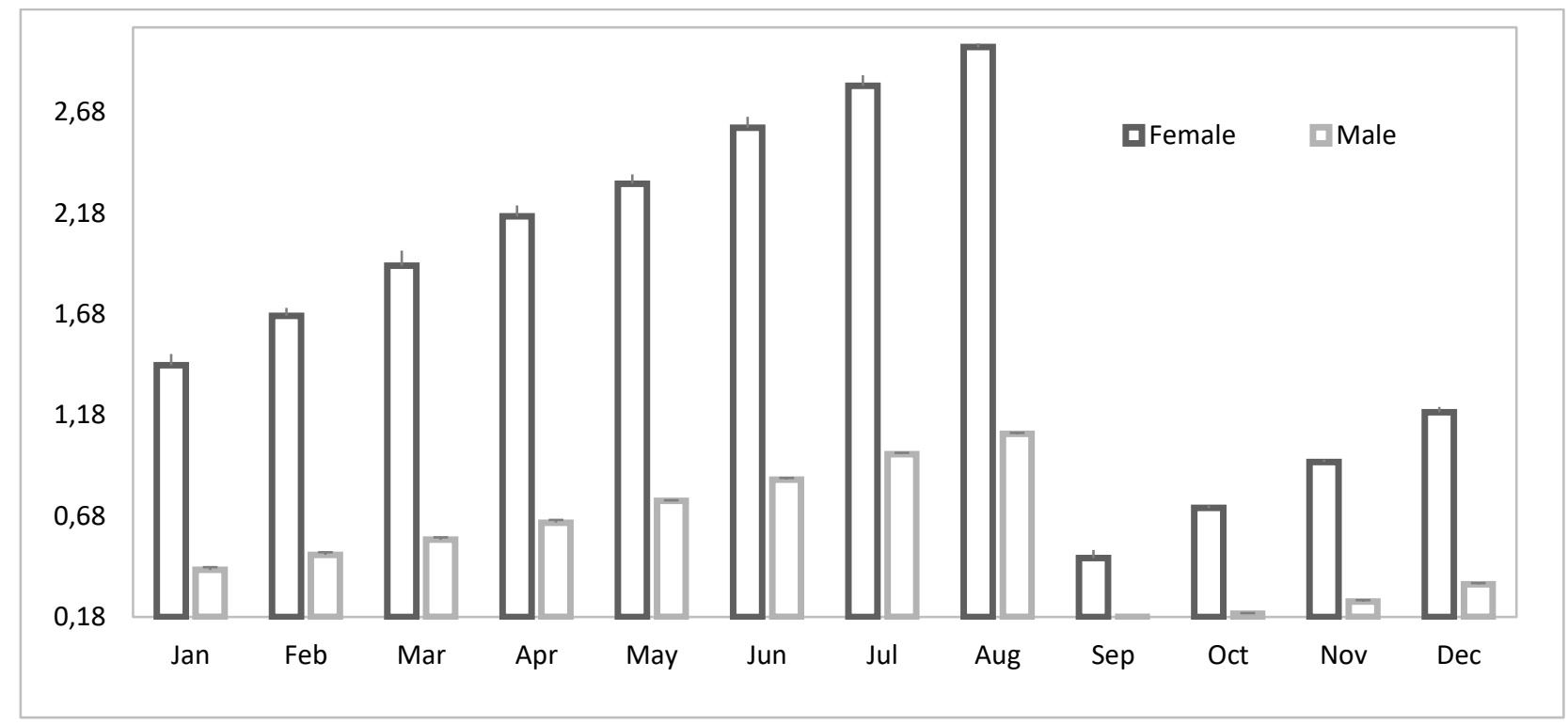

Figure 2. Monthly variation of GSI of female and male S. aor.

Table 1: Mean and standard deviation $( \pm S D)$ of body weight, ovary weight and fecundity of S. aor

\begin{tabular}{lcccc}
\hline Month & Total length $(\mathrm{cm})$ & Body weight $(\mathrm{g})$ & Ovarian weight $(\mathrm{g})$ & Fecundity \\
\hline April & $43.69 \pm 1.02^{\mathrm{a}}$ & $762.59 \pm 26.24^{\mathrm{a}}$ & $16.49 \pm 0.18^{\mathrm{a}}$ & $*$ \\
May & $46.83 \pm 0.15^{\mathrm{b}}$ & $901.41 \pm 20.81^{\mathrm{b}}$ & $20.96 \pm 0.12^{\mathrm{a}}$ & $59255.17 \pm 184.03^{\mathrm{a}}$ \\
June & $48.26 \pm 0.28^{\mathrm{b}}$ & $966.84 \pm 22.47^{\mathrm{c}}$ & $25.17 \pm 0.88^{\mathrm{b}}$ & $63314.67 \pm 153.60^{\mathrm{a}}$ \\
July & $51.1 \pm 0.22^{\mathrm{b}}$ & $1027.85 \pm 21.36^{\mathrm{c}}$ & $28.88 \pm 0.49^{\mathrm{b}}$ & $67342.67 \pm 253.71^{\mathrm{b}}$ \\
August & $51.33 \pm 0.19^{\mathrm{b}}$ & $1084.56 \pm 12.07^{\mathrm{c}}$ & $32.56 \pm 048^{\mathrm{b}}$ & $70048.86 \pm 131.99^{\mathrm{b}}$ \\
September & $39.85 \pm 1.65^{\mathrm{a}}$ & $705.12 \pm 90.55^{\mathrm{a}}$ & $3.35 \pm 0.69^{\mathrm{c}}$ & $*$ \\
\hline
\end{tabular}

*oocytes were too minute in size for counting. In column, means indicated by same letters stands for non-significant different from each other at $5 \%$ level of probability by DMRT. 


\section{Relationship Between Biometric Parameters of Fish}

The linear regression relationship of total length and body wight gave correlation coefficient of 0.909 (Figure 3) and represents strong explanation of fish body weight by their length. The relationship of fecundity alongside the body weight produced a correlation coefficient of 0.90 (Figure 4.B), and ovarian weigh to body weight was 0.955 (Figure 4.A).

\section{Histological Observation of Gonad}

The histological analysis of the ovarian cell during the reproductive season revealed that whole oocytes within an ovary did not matured synchronously and oocyte at different maturation phase were observed as well, which refers that $S$. aor are breed as batch spawner. In initiation of yolk vesicle phase, oocyte disruptions from the epithelium germinal layer and form an enveloped composed of follicular epithelium (Figure 5.I-II). Peripheral nucleoli appear at the bordering area next to the nucleus (thin lines) and cortical alveoli formed (Figure 5.II). The vitellogenesis phase was featured by the entrance of yolk molecules and fat vacuoles in the ooplasmic area of oocytes (Figure 5.IIIV). In histological observation of male gonad, the initial maturating stage was characterized by sperm duct (SD), visible but thin spermatocytes (SC) more in number with spermatogonia (S) (Figure 5.VII), while in matured phase, the spermatozoa were noticed (SZ) in the sperm duct (SD) and sperm duct being thicker or fuller due to the fluids in them (Figure 5.VIII)

\section{Nest Building Observations}

Most of the nests found near the periphery of the pond at 3-4 feet depth and they were circular in shape. Information recorded over the 12 month of study period. Nest building is one of the important parameters to know the breeding nature of the fish. The average diameter and depth of the nests were $99.67 \pm 1.83 \mathrm{~cm}$ and $24.63 \pm 2.04 \mathrm{~cm}$, respectively (Table 2 ). While the average total body length and depth of brood fishes were $50.26 \pm 1.39 \mathrm{~cm}$ and $6.82 \pm 0.43 \mathrm{~cm}$, respectively. There was no significance difference between the nest parameters and fish biometrics for all nest in the threepond system. Fries of $S$. aor were reported in the pond with artificial nests during July-August, while absent in the pond with without artificial nests. So, it can be concluded that the fish breeding and nursing of young took places within the nest.

\section{Discussions}

Body constitute of fish is found to be change in response to rearing water quality and season (Dygert, 1990; Hagmayer et al., 2018). Gonadosomatic index used as good an indicator of the spawning peak of teleost (Ali \& Kadir, 1996; Vlaming, 1972). The mean GSI values during the one-year study period showed the presence of a single breeding season in S. aor from July to August. There was a gradual rise in the GSI values from September to August. The highest gonado-somatic index of female and male $S$. aor was $3.00 \pm 0.02$ and $1.08 \pm 0.01$ respectively in August. On the other hand, the

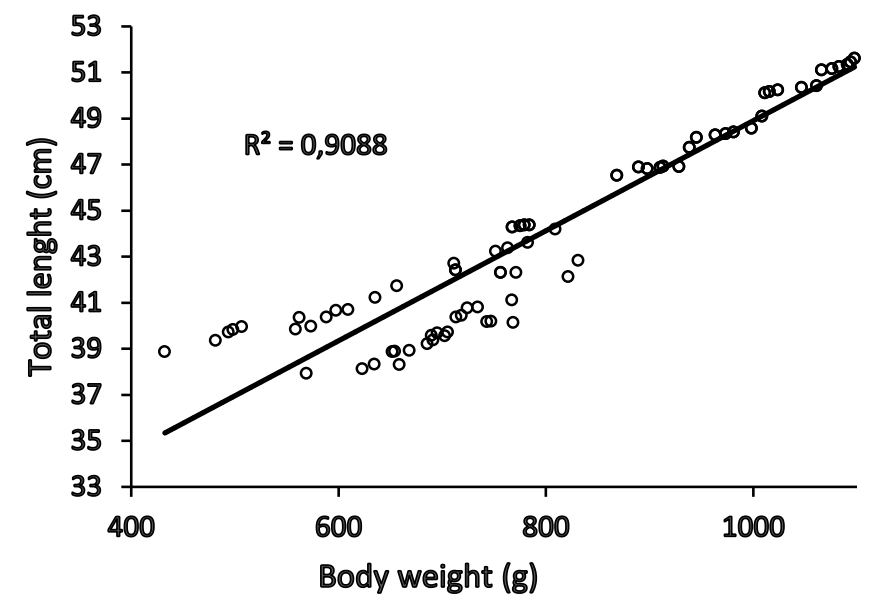

Figure 3. Relationship between total length and body weight of $S$. aor

Table 2. Diameter and depth of nest prepared by S. aor on the experimental ponds (No. of total nests=30)

\begin{tabular}{lccccc}
\hline \multirow{2}{*}{ Pond } & \multirow{2}{*}{ No. of nests } & \multicolumn{3}{c}{ Nest } & Fish \\
\cline { 2 - 5 } & 10 & Diameter $(\mathrm{cm})$ & Depth $(\mathrm{cm})$ & Total length $(\mathrm{cm})$ & Body depth $(\mathrm{cm})$ \\
\hline 1 & 10 & $99.88 \pm 1.83^{\mathrm{a}}$ & $25.73 \pm 1.95^{\mathrm{a}}$ & $50.38 \pm 1.38^{\mathrm{a}}$ & $6.75 \pm 0.45^{\mathrm{a}}$ \\
2 & 10 & $94.47 \pm 1.92^{\mathrm{a}}$ & $23.53 \pm 1.80^{\mathrm{a}}$ & $48.15 \pm 1.46^{\mathrm{a}}$ & $6.89 \pm 0.42^{\mathrm{a}}$ \\
3 & $97.90 \pm 01.93^{\mathrm{a}}$ & $21.53 \pm 1.90^{\mathrm{a}}$ & $46.38 \pm 1.42^{\mathrm{a}}$ & $6.69 \pm 0.47^{\mathrm{a}}$ \\
\hline *All values are expressed as Mean \pm SE. In column, means indicated by same letters stands for non-significant different from each other at $5 \%$ \\
\multicolumn{4}{l}{ level of probability by DMRT }
\end{tabular}



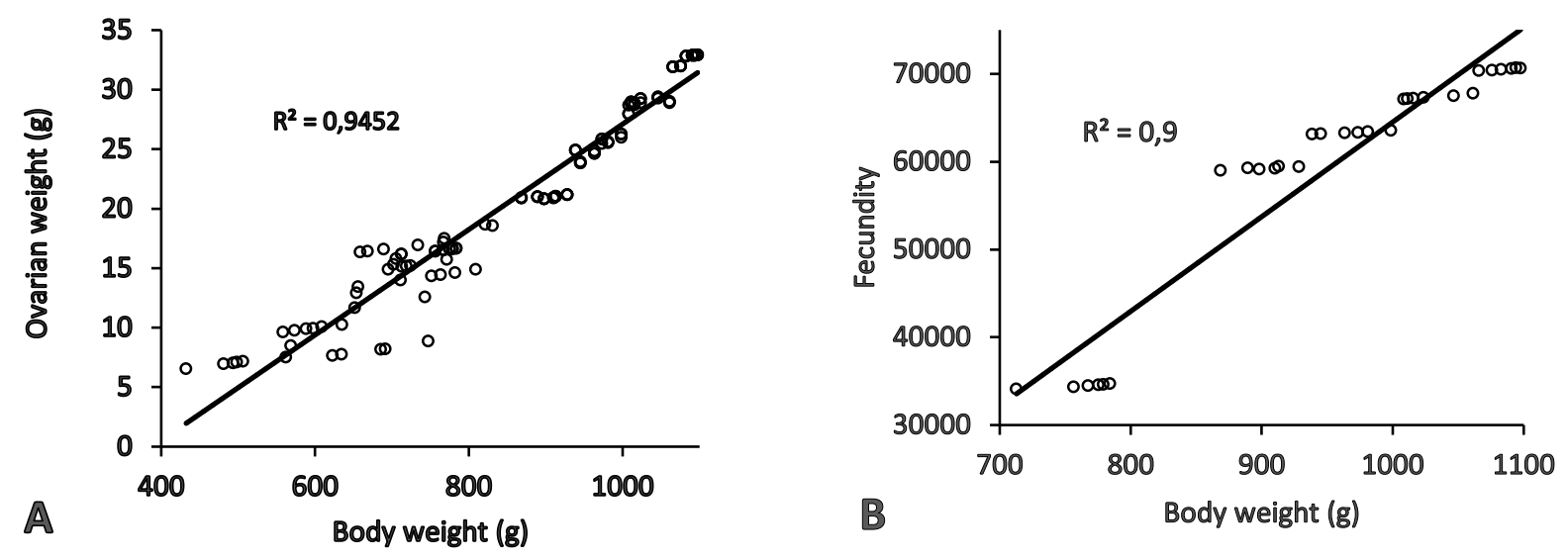

Figure 4. A. Relationship between ovarian weight and body weight, and B. fecundity and body weight of female S. aor

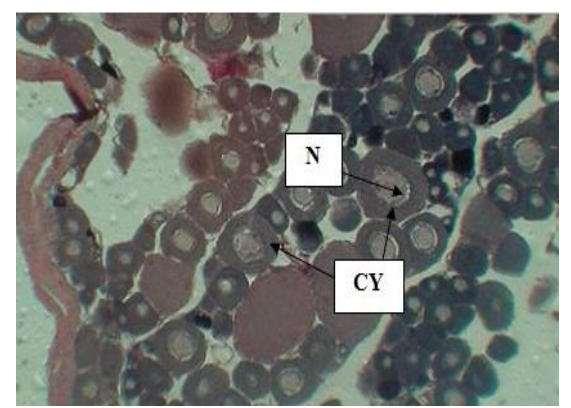

$\mathbf{I}$

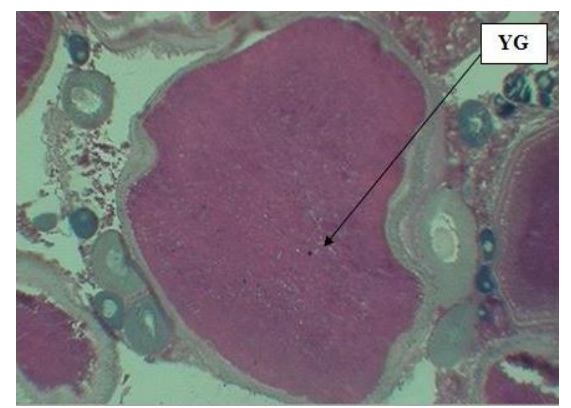

IV

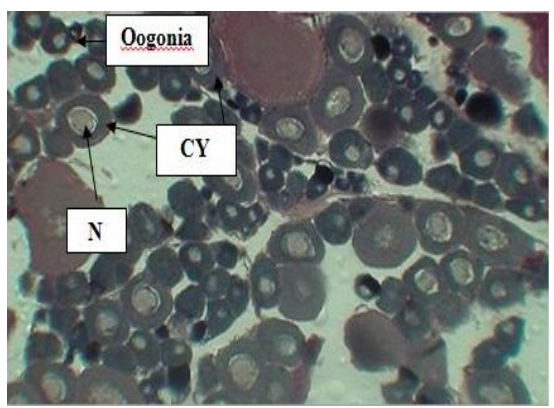

II

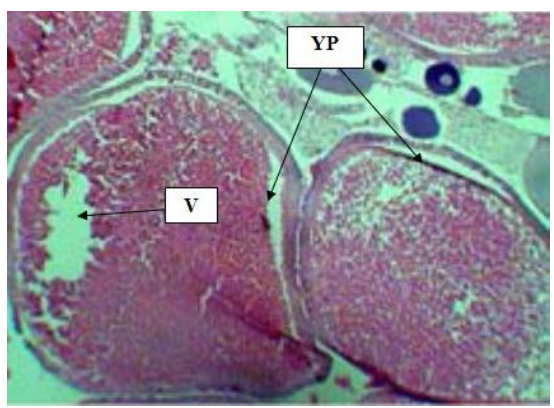

$\mathbf{V}$

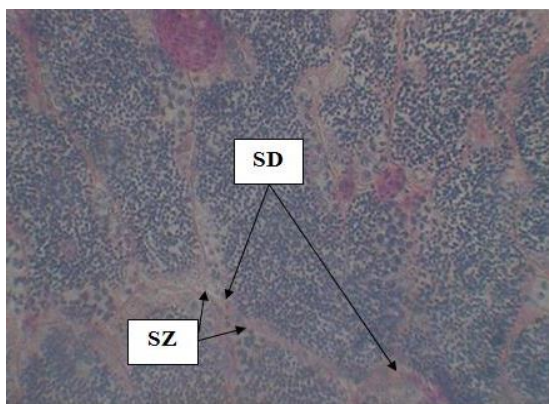

VII

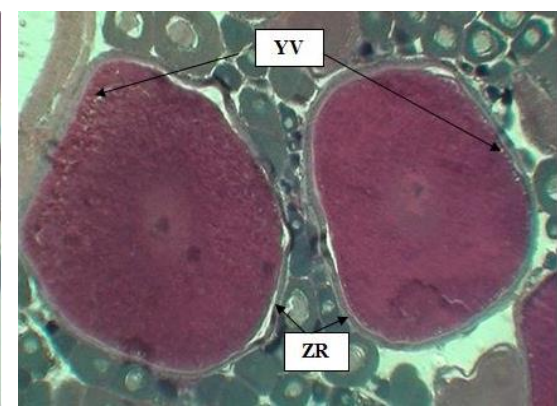

III

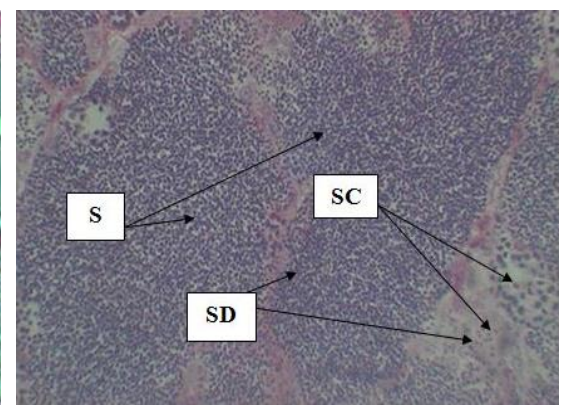

VI

Figure 5. Plate I: Early perinucleolar stages in the ovary (January to February, H\&E $\times 10$ ); Plate II: Late perinucleolar oocyte (LPO) stage in the ovary (March to April, H\&E $\times 10$ ); Plate III: Yolk vesicle stage of oocytes (YVO) in the ovary (May and June, H\&E $\times 10$ ); Plate IV: Early yolk-granule stage of oocytes (YGO) in the ovary (July (H\&E $\times 10)$; Plate V: Late yolk-granule stage of oocytes (YGO) in the ovary (August, H\&E $\times 10$ ); Plate VI: Maturing stage of testis of male S. aor in May and June (H\&E $\times 10)$; Plate VII. Mature stage of testes of male S. aor in July and August (H\&E $\times 10)$. (N-nucleus, CY-cytoplasm, YV-yolk vesicles, ZR-zona radiata, YG-yolk globules, YP-yolk protein, V-fat vacuoles, S-spermatogonium, SC-spermatocytes, SD-spermatids, SZ-spermatozoa). 
lowest gonadosomatic index of female and male and the lowest was $0.47 \pm 0.04$ and $0.86 \pm 0.01$ respectively in September. This indicates that the breeding season of $S$. aor lasts for long duration from April to August and peak in July to August. Similar trend in GSI value has been observed by several previous researches who had recorded maximum value of gonadosomatic indices during breeding season for both sexes as 6.363 in Pomadasys stridens (Amtyaz et al., 2013), 22.85\% \pm 20.00 in Chrysichthys auratus (Ragheb, 2016) and 12.50 \pm 4.97 in Menoda Catfish, Hemibagrus menoda (Shehu Jega et al., 2018). As gonads continued to be matured their weight tend to be increased for deposition of maturing molecules and also ovarian mass risen dramatically due to the reception of vitllogenine protein from liver in breeding season. he fecundity variation is common in fish and correspondent to species, size, and area (Gupta, 2014; Tessema et al., 2020). The low oocytes number is related with strong maternal and paternal attention (Cimadomo et al., 2018; Fávaro et al., 2005; Milachich \& Shterev, 2016). The absolute fecundity in present research ranged between 59255 to 70048 and seems to be highly fecundated in comparison to other catfish species. The value of absolute fecundity was between 785-14066 oocytes in female feral catfish, Clarias macrocephalus (Ali, 1993), 2000- 20600 eggs for female T. tandanus in the Gwydir River (Davis, 1977). Current findings were correlated with previous research in Asian striped catfish Mystus vittatus (Hossain et al., 2006), Striped Dwarf Catfish Mystus tengara (Mitu et al., 2014), and in Mystus cavasius (Latif et al., 2018). Total length, body weight and fecundity seem to be correlated in different fish species (Hossain et al., 2017; Kohinoor et al., 2013; Mian et al., 2020). Present study also indicates that fecundity of $S$. aor correlates with body weight. Several researches have noted positive $r^{2}$ value for total length and body weight (Schwartz \& Jachowski, 1965). A research revealed $r^{2}$ of 0.965 for Pseudomystus siamensis (Jonathan et al., 2013), $r^{2}=0.836$ for $H$. nemurus (Jonathan et al., 2013) and $r^{2}>0.9$ for Long snouted Catfish, Plicofollis argyropleuron in Malaysia (Rosli \& Isa, 2012). The regression results between fecundity, ovarian weight and body in the present study indicated that the fecundity of $S$. aor had a linear relationship with the body weight where $R^{2}>0.9$ for both cases. The oocytes output is found to be increased with increasing size and large fishes tend to have more gonadal mass as well as total oocytes numbers (Hagmayer et al., 2018; Kulabtong, 2016). However, seasonal influences are also key in determining the sequential changes in the ovary, size of fish as well as their spawning terms (Helmizuryani et al., 2020; Kapil et al., 2011).

Histological features of gonadal cell pride key information regarding maturation phases, and spawning schedule (Cimadomo et al., 2018; Jannatul et al., 2015; Jega et al., 2018; Uddin et al., 2017). Ovarian growth phases in S. aor was investigated in order to disclose the pattern and schedule of designated growth phase and development phase of gonadal germ cells. It has been noted well that the fish found solely in immature phases during November to April. Ovarian yolk vesicle phase acted in the month of May to June whereas granular phases of yolk growth were located in the month of July to August. The ovarian development of S. aor was group asynchronous in nature revealed from histological examination. The present results were agreed with other investigation on Rita rita (Rahman \& Mollah, 2014), Clarias lazera (Emam \& Abughrien, 2014) and Clarias gariepinus (Elias et al., 2018; Okoye et al., 2018; Tyor \& Pahwa, 2017). Following the histological examination of male gonad, the testicular germ cell stages of spermatogonia (S), spermatocyte (SP), spermatozoa (SZ) were observed during May to August. Current findings agreed with former research in other catfish P. hypophthalmus (Manosroi et al., 2004) and Pangasianodon hypophthalmu (Hassan et al., 2011).

The result of nesting in current study give an assumed of constructing nests by the brood fishes that are nearly two times larger of their total length, although nest's depth is counted as half of their total length. Nesting is one of the important aspects to know the breeding habit, breeding season and parental care of fish and also serve to attract the potential partner for successful breeding and courtships behavior (NavarreteFernández et al., 2014; Pärssinen et al., 2019). The purpose of nesting in $S$. aor might have both parental nursing and reproductive functions as nest were found in both pre-spawning and post-spawning periods.

\section{Conclusions}

Information on reproductive biology is important for planning, conservation, and management of a threatened fish species. The results of the study would be effective tools towards manipulation of management and protection plans for sustainable conservation and captive growth. The information gathered through the present experiment may be used for better management of current Sperata aor fishery in Bangladesh as well as their future conservation strategies and also for induction this species as a potential candidate into commercial aquaculturer.

\section{Ethical Statement}

The research has been dully conformed with all sorts of regional, national, and institutional animals' ethics approval.

\section{Funding Information}

The research has been funded by Bangladesh Agricultural Research Council, (BARC), Bangladesh.

\section{Author Contribution}

The manuscript comprises postgraduate research project of first other. The order of other authors list 
reflects the chronology of contribution by different author in current research work. However, the last author will be treated as team leader as per the university rules of authorship in teamwork.

\section{Conflict of Interest}

The authors declare that they have no conflict of interest.

\section{References}

Ali, A. B. (1993). Aspects of the fecundity of the feral catfish, Clarias macrocephalus (Gunther), population obtained from the rice fields used for rice-fish farming, in Malaysia. Hydrobiologia, 254(2), 81-89. https://doi.org/10.1007/BF00014311

Ali, A. B., \& Kadir, B.-K. A. (1996). The reproductive biology of the cyprinid, Thynnichthys thynnoides (Bleeker), in the Chenderoh Reservoir- a small tropical reservoir in Malaysia. Hydrobiologia, 318(3), 139-151. https://doi.org/10.1007/BF00016676

Amtyaz, Khan, M. A., Khan, M. Z., \& Hashmi, M. U. (2013). Studies on Gonadosomatic Index \& Stages of Gonadal Development of Striped piggy fish, Pomadasys stridens (Forsskal, 1775) (Family; Pomadasyidae) of Karachi Coast, Pakistan. Journal of Entomology and Zoology Studies, 1(5), 28-31.

Bolis, C. L., Piccolella, M., Dalla Valle, A. Z., \& Rankin, J. C. (2001). Fish as model in pharmacological and biological research. Pharmacological Research, 44(4), 265-280. https://doi.org/10.1006/phrs.2001.0845

Brooks, S., Tyler, C. R., \& Sumpter, J. P. (1997). Egg quality in fish: what makes a good egg? Reviews in Fish Biology and Fisheries, 7(4), 387-416. https://doi.org/10.1023/A:1018400130692

Cimadomo, D., Fabozzi, G., Vaiarelli, A., Ubaldi, N., Ubaldi, F. M., \& Rienzi, L. (2018). Impact of Maternal Age on Oocyte and Embryo Competence. Frontiers in Endocrinology, 9, 327. https://doi.org/10.3389/fendo.2018.00327

Davis, T. L. O. (1977). Reproductive biology of the freshwater catfish, Tandanus tandanus Mitchell, in the Gwydir River, Australia. II. Gonadal cycle and fecundity. Marine and Freshwater Research, 28(2), 159-169. https://doi.org/10.1071/MF9770159

Dygert, P. H. (1990). Seasonal Changes in Energy Content and Proximate Composition Associated with Somatic Growth and Reproduction in a Representative Age-Class of Female English Sole. Transactions of the American Fisheries Society, 119(5), 791-801. https://doi.org/10.1577/15488659(1990)119<0791:SCIECA >2.3.CO;2

Elias, N., Abouelghar, G., Sobhy, H., Elmeniawy, H., \& Elsaiedy, E. (2018). Sublethal effects of the herbicide thiobencarb on fecundity, histopathological and biochemical changes in the African catfish (Clarias gariepinus). Iranian Journal of Fisheries Sciences, O(0), 1589-1614. https://doi.org/10.22092/ijfs.2018.119669.

Emam, M. A., \& Abughrien, B. (2014). Seasonal Histological Changes in Gonads of the Catfish (Clarias lazera). Fisheries and Aquaculture Journal, 05(01), 3-6. https://doi.org/10.4172/2150-3508.1000087

Fávaro, L. F., Frehse, F. de A., Oliveira, R. N. de, \& Schwarz
Júnior, R. (2005). Reprodução do bagre amarelo, Cathorops spixii (Agassiz) (Siluriformes, Ariidae), da Baía de Pinheiros, região estuarina do litoral do Paraná, Brasil. In Revista Brasileira de Zoologia (Vol. 22, pp. 1022-1029). scielo.

Feist, S. W. (2009). Atlas of fish histology - Edited by F. Genten, E. Terwinghe and A. Danguy. Journal of Fish Biology, 75(3), 757-758. https://doi.org/10.1111/j.10958649.2009.02318_3.x

Gupta, S. (2014). Feeding and Breeding Biology of Amblypharyngodon mola - A Review. International Journal of Aquatic Biology, 2(2), 85-90. https://doi.org/10.22034/ijab.v2i2.35

Hagmayer, A., Furness, A. I., Reznick, D. N., \& Pollux, B. J. A. (2018). Maternal size and body condition predict the amount of post-fertilization maternal provisioning in matrotrophic fish. Ecology and Evolution, 8(24), 1238612396. https://doi.org/10.1002/ece3.4542

Hassan, A., Azmi Ambak, M., \& Samad, A. P. A. (2011). Crossbreeding of Pangasianodon hypophthalmus (Sauvage, 1878) and Pangasius nasutus (Bleeker, 1863) and their larval development. Journal of Sustainability Science and Management, 6(1), 28-35.

Helmizuryani, D., Muslimin, B., Aminah, R. I. S., \& Khotimah, K. (2020). The gonadal maturation of climbing perch, Anabas testudineus (Bloch, 1792) with dietary supplement add on feed. AACL Bioflux, 13(2), 885-892.

Hossain, M. A., Akter, M., \& Iqbal, M. M. (2017). Diversity of Fish Fauna in Kusiara River (Fenchungonj Upazilla), Northeast Bangladesh. Journal of Aquaculture in the Tropics, 32(1), 1-13.

Hossain, M. Y., Ahmed, Z. F., Leunda, P. M., Roksanul Islam, A. K. M., Jasmine, S., Oscoz, J., Miranda, R., \& Ohtomi, J. (2006). Length-weight and length-length relationships of some small indigenous fish species from the Mathabhanga River, southwestern Bangladesh. Journal of Applied Ichthyology, 22(4), 301-303. https://doi.org/10.1111/j.1439-0426.2006.00801.x

Iqbal, M. M., Alam, M. M. M., Kabir, M. A., \& Pálsson, S. (2018). Morphological and mitochondrial DNA variation revealed an undescribed lineage under the genus Sperata (Bagridae) in Bangladesh. Acta Zoologica, 99(2), 177-187. https://doi.org/10.1111/azo.12203

IUCN Bangladesh. (2015). Red List of Bangladesh Volume 1: Summary. In IUCN, International Union for Conservation of Nature, Bangladesh Country Office, Dhaka, Bangladesh.

https://doi.org/10.1017/CBO9781107415324.004

Jannatul, H., Chandra, R. N., Jannatul, F. M., Amzad, H. M., Mehed, H. M., Das, T. B., Sohel, M., Mahbub, I. M., Bodrul, M. M., \& Mosarof, H. M. (2015). Reproductive Biology of Striped Snakehead (Channa striata) from Natural. Annals of Veterinary and Animal Science, 2(6), 162-169.

Jonathan, B. Y., Maina, H. M., \& Musa, Y. M. (2013). Fisheries and Aquatic Science. Journal of Fisheries and Aquatic Science, 8(1), 287-290.

Kapil, S., Kulkarni, K. M., Gijare, S. S., \& Tantarpale, V. T. (2011). Seasonal changes of gonadosomatic index observed in the freshwater fish Channa punctatus. The Bioscan, 6(4), 571-573.

Khan, M. A., \& Nazir, A. (2019). Stock delineation of the longwhiskered catfish, Sperata aor (Hamilton 1822), from River Ganga by using morphometrics. Marine and Freshwater Research, 70(1), 107-113. 
https://doi.org/10.1071/MF17306

Khan, M., Nazir, A., \& Khan, S. (2016). Assessment of growth zones on whole and thin-sectioned otoliths in Sperata aor (Bagridae) inhabiting the River Ganga, India. Journal of Ichthyology, 56(2), 242-246. https://doi.org/10.1134/S0032945216020041

Kohinoor, A. H. M., Islam, M. S., Jahan, D. A., Khan, M. M., \& Hussain, M. G. (2013). Growth and Production Performances of Crossbred Climbing Perch Koi, Anabas testudineus in Bangladesh. International Journal of Agricultural Research, Innovation and Technology, 2(1 SE-Articles). https://doi.org/10.3329/ijarit.v2i1.13990

Kulabtong, S. (2016). Biological data of Burmese carplet Amblypharyngodon atkinsonii (Blyth, 1860) in South Myanmar (Cypriniformes Cyprin- idae ): a preliminary report. Biodiversity Journal, 7(2), 253-256.

Latif, M., Ullah, M. Z., Minhas, I. B., \& Latif, S. (2018). Lengthweight relationships of Mystus cavasius with special reference to body morphometric characters from river Chenab, Punjab, Pakistan. Pakistan. Journal of Entomology and Zoology Studies, 6(2), 2418-2421.

Manosroi, J., Meng-Umphan, K., \& Manosroi, A. (2004). Maturation Induction of Pangasius hypophthalmus Using Gonadotropin Releasing Hormone Analogue (GnRHa) in Combination with Domperidone, in Oil Suspension Dosage Forms. Asian Fisheries Science, 17, 39-49.

Mian, S., Shah, A. W., Hossain, M. A., Hossain, M. S., Iqbal, M. M., \& Debnath, P. (2020). Reproductive Biology of Captive reared spotted Spotted Snakehead, Channa punctatus (Bloch. Bulletin of Environment, Pharmacology and Life Sciences, 9(2), 8-15.

Milachich, T., \& Shterev, A. (2016). Are there optimal numbers of oocytes, spermatozoa and embryos in assisted reproduction? JBRA Assisted Reproduction, 20(3), 142149. https://doi.org/10.5935/1518-0557.20160032

Mitu, N. R., Alam, M. M., \& Pingalkar, S. R. (2014). Ovarian Development, Reproductive Cycle and Fecundity Indices in Mystus tengara. Journal of Biological and Chemical Research,31(740).

Navarrete-Fernández, T., Landaeta, M. F., Bustos, C. A., \& Pérez-Matus, A. (2014). Nest building and description of parental care behavior in a temperate reef fish, Chromis crusma (Pisces: Pomacentridae). Revista Chilena de Historia Natural, 87(1), 30.

https://doi.org/10.1186/s40693-014-0030-2

Nazir, A., \& Khan, M. A. (2017). Stock discrimination of Sperata aor from river Ganga using microsatellite markers: implications for conservation and management. Aquat. Living Resour., 30. https://doi.org/10.1051/alr/2017033

Neto, J. D. (2005). Gestão do uso dos Recursos Pesqueiros Marinhos (Issue January 2005). https://doi.org/10.1007/s13398-014-0173-7.2

Okoye, C. N., Udoumoh, A. F., Igwebuike, U. M., \& Okereke, C. T. (2018). Ovarian morphology and development of 3 to 8 months old African catfish, Clarias gariepinus. Comparative Clinical Pathology, 27(4), 887-891. https://doi.org/10.1007/s00580-018-2678-5

Pärssinen, V., Kalb, N., Vallon, M., Anthes, N., \& Heubel, K. (2019). Male and female preferences for nest characteristics under paternal care. Ecology and Evolution, 9(13), 7780-7791. https://doi.org/10.1002/ece3.5363
Ragheb, E. (2016). Reproductive biology of Catfish Chrysichthys auratus, Geoffroy Saint-Hilaire, 1809, (Family: Bagridae) from Damietta branch of the River Nile, Egypt. The Egyptian Journal of Aquatic Research, 42(3), 349-356.

https://doi.org/https://doi.org/10.1016/j.ejar.2016.07. 002

Rahman, M. M., \& Samat, A. F. (2020). Reproductive cycle, sexual maturity and fecundity of Nemipterus furcosus (Valenciennes, 1830). Aquaculture and Fisheries. https://doi.org/https://doi.org/10.1016/j.aaf.2020.07.0 06

Rahman, M., \& Mollah, M. F. A. (2014). Determination of breeding season of endangered riverine catfish rita (Rita rita Hamilton, 1822) by studying ovarian development and Gonado-Somatic-Index. Journal of the Bangladesh Agricultural University, 11 (2 SE-Fisheries). https://www.banglajol.info/index.php/JBAU/article/vie w/19938

Rosli, N. A. M., \& Isa, M. M. (2012). Length-weight and Lengthlength Relationship of Longsnouted Catfish, Plicofollis argyropleuron (Valenciennes, 1840) in the Northern Part of Peninsular Malaysia. Tropical Life Sciences Research, 23(2), 59-65.

https://pubmed.ncbi.nlm.nih.gov/24575234

Schwartz, F. J., \& Jachowski, R. (1965). The Age, Growth, and Length-Weight Relationship of the Patuxent River, Maryland Ictalurid White Catfish, Ictalurus catus. Chesapeake Science, 6(4), 226-229. https://doi.org/10.2307/1350817

Shehu Jega, I., Idris Miah, M., Arfin Huda, N., Atiqur Rah, M., Kaniz Fate, M., Mahfujul H, M., \& Shahjahan, M. (2018). Reproductive Biology of the Threatened Menoda Catfish, Hemibagrus menoda (Hamilton, 1822) in the Kangsha River, Bangladesh. Journal of Fisheries and Aquatic Science, 13(1), 39-48. https://doi.org/10.3923/jfas.2018.39.48

Tessema, A., Getahun, A., Mengistou, S., Fetahi, T., \& Dejen, E. (2020). Reproductive biology of common carp (Cyprinus carpio Linnaeus, 1758) in Lake Hayq, Ethiopia. Fisheries and Aquatic Sciences, 23(1). https://doi.org/10.1186/s41240-020-00162-x

Tyor, A. K., \& Pahwa, K. (2017). Ovarian Development of African Sharptooth Catfish (Clarias gariepinus, Burchell 1822) from Delhi Segment of River Yamuna. Journal of Fisheries and Aquatic Science, 12(3), 117-126. https://doi.org/10.3923/jfas.2017.117.126

Uddin, S., Hasan, M. H., Iqbal, M. M., \& Hossain, M. A. (2017). Study on the reproductive biology of Vietnamese climbing perch (Anabas testudineus, Bloch). Punjab University Journal of Zoology, 32(1), 1-7.

Van-Dyk, J. C., \& Pieterse, G. M. (2008). A histo-morphological study of the testis of the sharptooth catfish (Clarias gariepinus) as reference for future toxicological assessments. Journal of Applied Ichthyology, 24(4), 415422. https://doi.org/10.1111/j.1439-0426.2008.01127.x

Vlaming, V. L. (1972). Environmental control of teleost reproductive cycles: a brief review. Journal of Fish Biology, 4(1), 131-140. https://doi.org/10.1111/j.10958649.1972.tb05661.x

Volff, J.-N. (2005). Genome evolution and biodiversity in teleost fish. Heredity, 94(3), 280-294. https://doi.org/10.1038/sj.hdy.6800635 